\title{
Emrah İstek*
}

\section{$\ddot{O} z$}

İnsanlığın ilk seyyahı Hz. Adem'den günümüze kadar insanlar sürekli olarak yeryüzünü dolaşmaktadır. Bir yerden başka bir yere yapılan seyahat ancak gezip görülenlerin kaleme alınmasıyla bir seyahatnameye, gezen kişi de seyyaha dönüşmektedir. Bu bağlamda seyyahların gezdikleri yerlerin çokluğu ne kadar önemliyse, gördüklerini ve yaşadıklarını da ustalıkla eserlerine yansıtmaları o kadar önem arzetmektedir. Birçok Anadolu çocuğu gibi okumak için şehrini terkeden İhsan Süreyya Sırma, hayatının önemli bir bölümünü benzer amaçlarla yaptığı seyahatlerde geçirmiştir. Bir ilim yolculuğu şeklinde de değerlendirilmesi gereken bu seyahatleri, kendi ifadesiyle, "tarihçi" kimliğiyle gerçekleştirmiştir. Bu çalışmada İhsan Süreyya Hoca'nın seyahatleri ve bu kapsamda kaleme aldığı "Dağların Sirri", "Nehirleri Dili", "Seyahatnâme-i Süreyya", "Çin Müslümanlarl ve Çin'e Seyahat", "Ano Yemen'dir" ve "Yalan Dünyayı Adımlarken" adlı eserleri incelenmiştir. İhsan Süreyya Hoca'nın seyahat notlarında neleri öncelediği, verdiği mesajlar, bazı anekdotlar ve seyahatlerinin kapsamı bu çalışmada üzerinde durulacak konular arasındadır. Ayrıca seyahatlerinin finansal yönü, kurgusal ve gerçekliği birarada yansıtması ve özel önem verdiği bazı ülkeler de bazı yönleriyle ele alınmıştır.

Anahtar Kelimeler: İhsan Süreyya Sirma, Seyyah, Seyahat, Seyahatname.

\section{“HISTORIEN TRAVELER" IHSAN SUREYYA SIRMA}

\begin{abstract}
People are constantly walking around the earth, since the first traveler of humanity Hz. Adam. Travels become a travel book, and the traveler becomes a traveler only by writing what is seen. In this context, travelers are expected to masterfully reflect what they see and experience as much as the places they visit.

Like many Anatolian children, İhsan Süreyya Sırma, who traveled to study, spent a significant part of his life on travels. Most of these travels, which should also be considered as a science journey, were carried out under the identity of "historian". In this study, the travels of İhsan Süreyya Hoca and his works "Dağların Sirrı (The Secret of the Mountains), Nehirlerin Dili (The Language of the Rivers), Seyahatnâme-i Süreyya (The Travel Book of Süreyya), Çin Müslümanları ve Çin'e Seyahat (The Muslims of China and Travel to China, Ano Yemen (Yemen) and Yalan Dünyay1 Adımlarken (Stepping into the World of Lies) are examined. This study will focus on what Hodja paid attention to in his travel notes, messages and some anecdotes and scope of his travels.
\end{abstract}

Article Types / Makale Türü: Research Article / Araştırma Makalesi

Received / Makale Geliş Tarihi: 10.04.2019, Accepted / Kabul Tarihi: 20.01.2020

DOI: https://doi.org/10.26791/sarkiat.629438

*Ağrı İbrahim Çeçen Üniversitesi, Fen Edebiyat Fakültesi, Tarih Bölümü, eistek@agri.edu.tr

ORCID ID: https://orcid.org/0000-0003-1407-3609 
Keywords: İhsan Süreyya Sirma, Travel, Traveler, Travel Book.

\section{GÍRIŞ}

Seyyahların ortak özelliklerinden olan merak duygusu İhsan Süreyya Sırma için de geçerlidir. Hatta ondaki merak duygusu, dağlar, nehirler, denizler ve ülkeler aşmasında en önemli faktördür. Bunun yanında "ögrrenme aşkl", onu bir şehirden diğerine savuran bir başka yönüdür. Bir seyyahın ve seyahatnamesinin güçlü ve tutarlı tarafı, olayları gördügü anda veya en kısa sürede kayıt altına almasıdır. Bu yönüyle İhsan Süreyya Sırma, eserlerinde de görüleceği üzere, gözlemlediği şeyleri yerinde not etme gayreti içinde olmuştur. Notlarını bir dağ başındaki kayanın duldasında, bir nehrin kıyısında veya bir uçak koltuğunda vakit kaybetmeden almıştır. Bunu yapamadığı zaman, gezdiği günün gecesi, kendi söylemiyle "kafasını yastığa koymadan önce" gözlemlerini kâğıda dökmüştür. Bunun için en çok tercih ettiği yer kaldığı otelin veya misafir olduğu evin odasıdır. Özellikle Yemen gezisinde notlarının birçoğunu otele varır varmaz yazdığ anlaşılmaktadır. Meşhur seyyahlardan Busbecq ${ }^{1}$ gibi seyahatlerini dönüşünden sonra mektuplar halinde neşreden veya İbn-i Batuta ${ }^{2}$ gibi bir kâtibe yazdıranlar düşünüldüğünde İhsan Süreyya Hoca gibi anlık kaydedenlerin seyahat notlarının kıymeti daha iyi anlaşılmaktadır.

$\mathrm{Bu}$ çalışmada İhsan Süreyya Hoca'nın hayatının önemli bir bölümünü kapsayan seyahatler, konu olarak seçilmiştir. Seyahatlerin kapsadığı yerler, seyahat edilen ülkeler ile bu gezilerin hangi yöntem ve yollarla gerçekleştiği incelenmiştir. Bu bağlamda Hoca'nın tanıştığı şahsiyetler, katıldığı konferansla kongreler ve edindiği yeni tecrübeler, bir bütün halinde verilmeye çalışılmıştır. Bütün bunların yanı sıra İhsan Süreyya Hoca'nın dile getirmeyi ihmal etmediği mukayeseli Müslüman kimliği ve Müslümanların sıkıntıları da çalışma kapsamındaki seyahat notları çerçevesinde ele alınmıştır.

\section{Seyahat Yaptı̆̆ı Yerler}

Pervari'nin bir köyünde oturan Şeyh Müşerref'e, "okuma izni" almak üzere Botan Çayı'nı geçerek gitmesi ile başlayan ${ }^{3}$ seyahat serüvenine hâlen devam eden İhsan Süreyya Hoca'nın seyahat ettiği ülkelerin sadece isimlerini bile yazmak hayli geniş bir yer tutar. Seyahatnâme-i Süreyya'da "doksana yakın ülke gezmiş biri olarak..." demekle gezdiği ülkelerin sayısını kendisi vermiştir. Bu sayıyı 1998 yılında veren seyyah, başka bir eserinde yazdığı aynı yıla ait takdim yazısında bu rakamı "altmışı aşkın" şeklinde vermiştir. ${ }^{5}$ Her iki sayının arasında büyük bir fark olmakla birlikte iki ifade de birbirini tekzip etmemektedir. Bu ülkeler Antartika haricindeki beş kıtada bulunduğundan, ülkelerin bulunduğu her kıtayı da gezdiği anlaşılmaktadır. Birçok

\footnotetext{
${ }^{1}$ Busbecq Viyana'dan başladığı elçilik görevini Amasya'ya kadar giderek icra etmiş ve anılarını dönüşte kaleme aldığı mektupları birleştirmek suretiyle "Türk Mektupları" adlı eserini neşretmiştir. Eser için bk. Ogier Chiselin de Busbecq, Türk Mektuplarl. Kanuni Döneminde Avrupalı Bir Elçinin Gözlemleri (15551560), Çev. Derin Türkömer (İstanbul: Türkiye İş Bankası Kültür Yayınları, 2016).

2 İbn-i Batuta yıllar süren seyahatini tamamladıktan sonra Fas Sultanının isteği üzerine anılarını Muhammed bin Muhammed bin Cuzeyy el-Kelbî’ye yazdırmıştır. İbn-i Batuta, Büyük Dünya Seyahatnamesi (İstanbul: Yeni Şafak, ts.), 22.

3 Adnan Demircan, İhsan Süreyya Sirma Kitabı. Pervari'den Paris'e (İstanbul: Beyan Yayınları, 2018), 50-51.

${ }^{4}$ İhsan Süreyya Sirma, Seyahatnâme-i Süreyya (İstanbul: Beyan Yayınları, 2010), 41.

5 İhsan Süreyya Sırma, Yalan Dünyayı Adımlarken (İstanbul: Beyan Yayınları, 2011), 12.
} 
ülkeye birkaç defa hatta dört defa giden İhsan Süreyya Hoca, her gittiği zamanda farklı şeyler yapmaya ve farklı şehirlere gitmeye özen göstermiştir.

İhsan Hoca, bazı ülkeler hakkında oldukça fazla malumat vermiştir. Çin, Yemen, Güney Afrika Cumhuriyeti, Malezya ve Endülüs bunlardan öne çıkanlar arasındadır. Ayrıca Yemen ve Çin gezilerini kapsayan müstakil seyahat eserleri bu iki ülke hakkında geniş malumat edinmeye imkân sağlamaktadır.

\section{İlim Yolculuğu}

Hayatını Kur'an-1 Kerim düsturunca yaşamaya gayret eden İhsan Süreyya Sırma'nın seyahatlerinin ilmi bir alt yapısı bulunmaktadır. "Sizden önce (ki milletlerin başından) nice olaylar gelip geçmiştir. Yeryüzünde gezin dolaşın da yalanlayanların sonunun nasıl olduğunu bir görün." Ve "De ki: 'Yeryüzünde gezin dolaşın da (Peygamberleri) yalanlayanların sonu nasıl olmuş bir görün'"7 ayetleri, İhsan Hoca'nın yolculuğunun ana gayesi olarak görülebilir. Zira Tarihçi Seyyah ${ }^{8}$ gezdiği yerleri bu amaç etrafında müşahade etmiş ve önceki kavimlerin yaşadıklarından ders çıkartan bir yaklaşım sergilemiştir. Bu bakış açısı, "Dağların Sırrı" ve "Yalan Dünyayı Adımlarken" adlı eserlerinde daha yoğun bir şekilde göze çarpmaktadır.

Siirt'in Pervari ilçesinde başlayan ve Paris'e kadar uzanan ilim serüveni, doktora eğitimi döneminde de devam etmiştir. Tunus'a Arapça eğitimi için yaptığı seyahat yine bir ilmi yolculuktur. Bundan sonraki yolculuklarının çok büyük bir kısmı bilgiyi öğrenmekten ziyade, ilmini aktarmak için yaptığı seyahatlerin başladığı dönemdir. Bu bağlamda davet edildiği, konferans, kongre ve sempozyumlar, seyahat etmek için finansal destek sağlamak dışında, ilmini paylaşmak için tereddüt etmeden katıldığ 1 akademik aktiviteler olmuştur. Konferansları dağlara tırmanmak için önemli bir firsat olarak gören Tarihçi Seyyah, bu durumu da gizlememiştir. Pirenne Dağlarındaki Ronçevaux Geçidi buna açık bir örnektir. ${ }^{9}$ Yine Klimanjaro Dağı'nı bir konferans daveti neticesinde görmüştür. Öyle anlaş1lıyor ki İhsan Hoca, adeta dağlara çıkmak için konferansları kovalamış veya konferansların sunduğu firsatları geri çevirmemiştir. ${ }^{10}$

Hoca, seyahat kitaplarında gördüklerini ve tecrübelerini aktarmak suretiyle genel kültür yüklemesi yapmasının yanı sıra gerçek anlamda temel eserlerin isimlerini vererek okuyucunun literatür bilgisine de katkı sağlamaktadır. Ancak İhsan Hoca'nın zikrettiği eser isimleri -sürekli tevazu gösterdiği- yabancı dil bilgisi olanlar için bir anlam ifade ettiğini belirtmek gerekir. Zira bu kitaplar genellikle Fransızca veya Arapça yazılan kaynak eserlerdir. Bunun dışında katıldığı kongre, konferans ve sempozyumlardaki katılımcıların sundukları tebliğler hakkında bilgi vermesi de okuyucu için önemli bir kazanımdir.

Her bir seyahat İhsan Süreyya Hoca'ya yeni bir tecrübe edinme ve yeni bir bilgiyi öğrenme aracı olmuştur. Örneğin, Almanya'nın Recklinghausen kentinde Prostestan bir kadın papazla karşılaşınca, kadından papaz olabileceğini öğrenmiş ve “bilgisizliğì”nden utandığını belirtmiştir. " "Çok okuyan $m \imath$ çok gezen $m i$ bilir?" klişe sorusu İhsan Süreyya Sırma'da iki yönlü karşılık bulan bir sorudur. Ancak "gezen bilir" çıkarımı,

\footnotetext{
${ }^{6}$ Kur'an-1 Kerim, Âl-i İmrân: 137.

${ }^{7}$ Kur'an-1 Kerim, En'âm: 11.

8 İhsan Süreyya Sırma için bu tanımlama sıkça kullanılacaktır. Bu ifade Hoca'nın kendisine aittir.

Özellikle "Dăgların Sırrı" adlı eserinde kendinden bahsederken, bu ifadeyi kullanmayı tercih etmiştir.

${ }^{9}$ İhsan Süreyya Sırma, Dağların Sırrı (İstanbul: Beyan Yayınları, 2017), 107.

${ }^{10}$ Sirma, Dă̆ların Sirrı, 121-123.

${ }^{11}$ Sirma, Seyahatnâme-i Süreyya, 113.
} 
İhsan Hoca için aralıksız öğrenme sürecinin merdiven basamakları gibi olmuş, gittiği her bir ülke ve şehirde bu basamakları adım adım çıkarak ilmi birikimini artırmıştır. Bu bağlamda Hoca'nın ilim serüveni ile ülkeler serüveninin başa baş gittiği söylenebilir. Çünkü her bir ülke aktif bir öğrenme süreci, ilgili örnekte olduğu gibi, içinde barındırmaktadır.

\section{Seyahatlerin Parasal Kaynağı}

Seyyahların yaşadıkları problemlerin başında finansal zorluklar gelmektedir. İmparatorluklar dönemindeki seyyahlar bu problemi Ogier de Busbecq gibi üstlendikleri diplomatik misyonlarla veya bu misyon heyetlerine tabi olarak çözebilmekteydiler. Bunların arasında tüccar veya (Jean-Babtiste Tavernier) din görevlisi olanlar (Stephan Gerlach); devletin sunduğu fon karşılığı gidenler (Joseph de Tournefort) veya gittiği yerlerdeki ihsanlar ve resmi görevlerle seyahatlerini karşılayan (İbn-i Batuta, Evliya Çelebi) seyyahlar sayılabilir. Günümüz seyyahları için ise finansal sorunların üstesinden gelmenin türlü yolları bulunmaktadır. Başta aileden gelen maddi destek olmak üzere iş gezileri, medya kuruluşları için gezi çekimleri yapmak veya sosyal medya üzerinden sponsorluk sağlamak bunlardan bazılarıdır. İhsan Süreyya Hoca için bu sorun yukarıda zikredilen konferans, kongre ve sempozyumların sağladığı imkânlar haricinde, vefalı dostlarının sundukları kadirşinaslıkla birlikte kendi imkânları ile de zaman zaman bu sorunun üstesinden gelmeye çalıştığ1 görülmektedir. İhsan Hoca seyahatlerini nasıl finanse ettiğini şu cümlelerle açıklamaktadır:

“Bendeniz Amerika'dan Avusturalya'ya; Güney Afrika'dan İsveç'e kadar olan dünyamızda altmışa aşkın ülke gezdim. Muhtemelen bu satırları okuyanlar, haklı olarak, "hoca bu kadar yeri gezmek için nereden para getiriliyor?" diye düşüneceklerdir. Bu ülkelerin tamamına konferans vermek için gittim. Çocukluğumdan beri en çok sevdiğim hasletlerden bir tanesi değişik diller öğrenmek olduğundan; Allah'a şükür birkaç tane dil öğrendik ve bu diller, her tarafa gitmemizi kolaylaştırdı; anlatacaklarımızı o dillerde anlattık. Kısacası 'gezilerimde ekonomik boyutu aşan başka bir boyut var' demek istiyorum. Hatta bazen öyle anlar oldu ki, davet edildiğim ülke havaalanında birileri gelip beni almazsa, şehre gidecek kadar imkânım bile yoktu." ${ }^{2}$

Hoca bir başka yerde; "Hocam sen bu kadar yeri nasıl gezdin, bu paralar nereden, nasıl gidiyorsun?” sorusuna; “Bana, 'Gel Resûlullah'ı anlat.' diyorlar ben de gidiyorum. Onlar biletimi gönderiyorlar, otelimi sağllyorlar, yemeğimi de yediriyorlar ve gezdiriyorlar. Bu şekilde geziyorum."13 şeklinde manidar bir cevap vermiştir.

Burada Hoca'nın eklemediği ancak eserinde bahsettiği konuyla ilgili bir başka husus daha vardır ki o da bazı havalimanlarının sunduğu "free tour (ücretsiz tur)" imkânıdır. Singapur'u bir aktarmalı uçuş esnasında havalimanının sağladığı bu tur sayesinde ücretsiz olarak gezme imkânını kaçırmamıştır. ${ }^{14}$ Bütün bunların dışında İstanbul Büyükşehir Belediyesi'ndeki görevi dolayısıyla Dubai ve Barselona gibi şehirlere de seyahatte bulunmuştur.

İhsan Süreyya Sırma Hoca, konferanslardan birkaç gün önce söz konusu yere giderek veya kongre/konferans bittikten sonra birkaç gün daha kalarak bulunduğu şehri ve ülkeyi gezmiştir. Bu özelliği diğer akademisyenlerden farklı olarak bölgeyi tanımasına ve yakinen gözlem yapmasına olanak sağlamıştır.

\footnotetext{
${ }^{12}$ Sirma, Yalan Dünyayı Adımlarken, 12.

${ }^{13}$ Adnan Demircan, Ihsan Süreyya Sirma Kitabi. Pervari'den Paris'e, 391.

${ }^{14}$ Sirma, Yalan Dünyayı Adımlarken, 20-22.
} 
Konferans davetleri dışında da imkanların el verdiği ölçüde yaptığı seyahatler vardır. Örneğin, bir defasında şartları zorlayarak Endülüs'ü ziyaret etmek istemiştir. Bir türlü gidemediği bu topraklara ucuz uçak biletlerinin olduğunu duyan Tarihçi Seyyah, vakit kaybetmeyerek ucuz olan bu seyahati kaçırmamak için bir arkadaşından 100 Dolar daha bulmak zorunda kalmıştır. Ancak böylece seyahate çıkmış ve Quadalquivir Vadisi'ne gidebilmiştir. ${ }^{15}$

\section{Merak, Dert ve Cesaret}

Bir seyyah için merak, olmazsa olmazlardandır. Ancak İhsan Süreyya Hoca'da bunun biraz daha fazlası vardır. Yeterli cesaret ve merak, onu "Tarihçi Seyyah" yapan temel unsurlardır. $\mathrm{Bu}$ huy, kendisinin de defaatle zikrettiği gibi, bir yanının gazeteci olmasından ileri gelmektedir. ${ }^{16}$ Zira birçok yerde "gazeteci olduğumuz için dayanamadım sordum (veya) gittim" gibi merakının sebebini izhar etmiştir. Hatta gazeteci kimliğini havalimanında sigara içenlere polisin müdahale etmesi için dahi kullanmıştır. ${ }^{17}$

İhsan Süreyya Hoca'nın bulduğu firsatları değerlendirmeyi ihmal etmemesi de meraklı mizacının bir sonucudur. Bu merak duygusu, onu ya bir su kenarındaki insanların hikayesiyle veya bir dağın tepesindeki asırlık ağaçların altında başlayan bir hikaye ile başbaşa bırakmıştır. Bu hikayelerle dünyanın birçok meşhur dağında karşılaşan Hoca, kendi memleketindeki Ozim Dağı'nın hikayesini de yine bu merakın bir sonucu olarak kaleme almaktan geri durmamış, Ozim'in hikâyesini Ozim Köyünün kahvehanesindeki yaşlı bir köylünün ağzından kaleme almıștır. Bu "canlı tarihten" I. Dünya Savaşı dönemindeki Ermeni mezaliminin kötü karakteri olan Ermeni asıllı Lato'nun hikâyesi çıkmıştır. Rusların işbirlikçisi olan Lato, Siirt-Pervari üzerindeki Müslüman köylerindeki halkı katleden bir haindir. ${ }^{18}$ Arşivde bulduğu belgeyle hikâyeyi tamamlayan seyyahın bu durumu, yani olaylara dair merakı, onun sözlü hikâyelerin arkasını araştıran ilim adamlığıyla örtüşen bir hususiyettir.

Tarihçi Seyyahın en büyük derdi Müslümanların maruz kaldığı sorunlardır. Müslümanların durumlarını bir dağın başında, bir nehrin kenarında veya yürüdüğü şehrin bir sokağında sürekli olarak düşünmekte ve Müslümanca olan şeylere şükretmekte, gayrisi olan için de yüreğini sıkan derdi kağıda akıtarak, okuyucuya " $b u$ derdin farkında olmalısın" çağrısını yapmak suretiyle kalemiyle düzeltme yoluna gitmektedir. Müslümanların birbirini umarsızca ve başkalarının gözlüğünden bakarak yargılaması dertlerinden sadece birisidir. Örneğin, Sudan'a uzun ve meşakkatli bir yolculuk neticesinde gittiği 1998 yılında Sudan yönetiminin dünyaya ne kadar kötü anlatıldığını; "Birazcık param olsa, bizim laik ve demokrat geçinen taifenin tamamın bir uçağa doldurup Sudan'a götürür ve orada, kendilerinin mi, mevcut Sudan rejiminin mi daha demokrat olduklarını kendilerine gösterirdim"19 diyerek "umutsuz çağrısını" dillendirmiştir.

\footnotetext{
15 İhsan Süreyya Sırma, Nehirlerin Dili (İstanbul: Beyan Yayınları, 2017), 49-50.

16 İhsan Süreyya Hoca, bazı basılı yayın organlarında köşe yazıları yazmış ve bir televizyon kanalında da haftalık programlar yapmıştır.

${ }^{17}$ Sirma, Yalan Dünyayı Adımlarken, 123-125.

${ }^{18}$ Sirma, Dağların Strrt, 137-147.

${ }^{19}$ Sirma, Seyahatnâme-i Süreyya, 27-28.
} 
Hoca'nın çok önemli bir sorun olarak gördüğü başörtülü öğrencilerin ellerinden alınan eğitim özgürlüğ $\ddot{u ̈}^{20}$, seyahat notlarında öne çıkan konuların başında gelmektedir. $\mathrm{Bu}$ hususu hemen her gezisinde hiçbir şeyden veya kimseden çekinmeden dile getirmiştir. En çok da "Yalan Dünyayı Adımlarken" adlı eserinde bu soruna değinmiştir. Ayrıca Müslümanların genel hali de Hocayı sürekli rahatsız ettiğinden, bu durumu açıklamak için gözlemlediği birçok olay üzerinden Müslümanların hallerini yorumlamıştır. Hatta koala hayvanının tembelliği ile Müslümanların tembelliğini "koalalaşmış Müslümanlar" uyarlamasıyla örneklemiştir. ${ }^{21}$

İhsan Süreyya Hoca'nın seyahat eserlerinde, Müslümanların çektikleri sıkıntıların müsebbibi olarak gösterilen genel karakter "Batı", onun da uygulayıcısı olarak gördüğü Amerika'dır. Ona göre; Fujiyama'nın Hiroşimalı misafirinden, Kinto Dağı'ndaki Kızıldereli kemiklerine; Halepçe dramına şahitlik eden Şinirvi Dağı'na kadar birçok yerde kötülüğün müsebbibi Amerikan politikalarıdır. Ayrıca seyyahın ifadesiyle "Çağın Hitleri Şaron" ve "Halepçe katili Saddam" gibi Müslümanların başına bela olan "Kötüler", onun seyahatlerinin kötü karakterleri ve zulmün temsilcisidirler.

İhsan Süreyya Hoca'nın seyyah kimliğini oluşturan diğer bir unsur ise hür ve özgür olmak isteğidir. Kendisi bu karakterini Avrupa'da bir şehri gezerken dillendirmiştir. Hoca'nın hür ve özgür bırakmayı istediği karakteri ile bağdaştırdığı şehir, Freiburg (Hür Şehir)'dir. Şehrin hür olması hürriyet kimliğini sevmesinden dolayı hoşuna gitmiştir. ${ }^{22}$

\section{Vefa ve Dostları}

Birçok yerde vefalı dostları bulunan İhsan Süreyya Hoca'nın bu dostları onu gittiği şehirlerde yalnız bırakmayıp gezdirmiş, bulunduğu şehri tanımasına hatta yeni dostlar edinmesine vesile olmuşlardır. Bunların arasında, Çin'e beraber gittiği Nejat Bey, Tunus'lu Raşid Gannûşi, Yemen'de Hoca'yı gezdiren Gannûşi'nin talebesi ve üniversite hocası Ali Bey, 1979 yılında Beyrut havaalanında mahsur kalınca otele yerleşmesine yardımcı olan Lübnan Müftüsü Hasan Halid Bey ve saatlerce süren yolu aştıktan sonra Tur Dağı'na kendisini götüren Kahire'li arkadaşı Zeki Bey gibi dostları sayılabilir. $\mathrm{Bu}$ dostları aynı zamanda seyyah kimliğinin vazgeçilmez karakterleri olmuştur.

Birçok defa gittiği Amerika'da Cuma namazlarını veya vakit namazlarını mümkün oldukça farklı etnik, mezhebi ve cemaat gruplarının camilerinde kılmaya özen gösteren İhsan Süreyya Sırma, bunun sebebini "daha çok insanla tanışmak ve Kur'an ve sünnete bağlı her cemaate yakın olduğunu göstermek” olarak açıklamıştır. ${ }^{23}$

İhsan Hoca, gittiği ülkelerdeki Müslümanlarla namaz kılmış, onlara konferanslar vermiş, hatta onların zikir halkalarına da iştirak etmiştir. Zira Güney Afrika'daki Müslümanların zikrine katılması bunun bariz bir örneğidir. ${ }^{24} \mathrm{Bu}$ şekilde halkın dini yaşantılarını daha yakından müşahede edebilmiş ve yıllarca unutulmayacak dostluklar kurmuştur.

\footnotetext{
2028 Şubat 1997 gününde Milli Güvenlik Kurulu'nun aldığı kararlar uyarınca başlayan ve halk arasında "Post Modern Darbe" olarak hatırlanan dönem için kullanılmaktadır. Bu darbe dönemiyle beraber başörtülü öğrencilerin, başörtülü olarak eğitimlerini sürdürmeleri yasaklanmıştır.

${ }^{21}$ Sirma, Yalan Dünyayı Adımlarken, 28.

${ }^{22}$ Sirma, Seyahatnâme-i Süreyya, 60.

${ }^{23}$ Sirma, Yalan Dünyayı Adimlarken, 182.

${ }^{24}$ Sirma, Yalan Dünyayı Adımlarken, 240-241.
} 


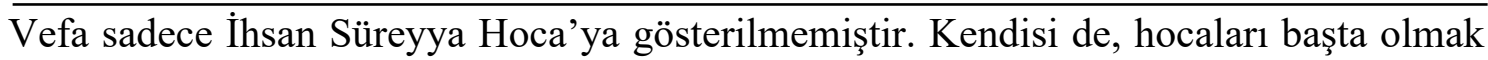
üzere, tanıştığ 1 dostlarına her daim vefasını eksik etmeyen bir karaktere sahiptir. Örneğin Hocası Muhammed Hamidullah'ı Fransa'daki öğrencilik yıllarında yalnız bırakmamış, yıllar sonra hocasının Amerika'da olduğunu öğrendiği zaman -yine vefalı bir dostun yardımıyla- bulunduğu eyaletten diğerine bir günlük araba yolculuğu yaparak hocasını kısa bir an için de olsa görmüş ve onun elini öpmüştür. Yine Hamidullah Hoca'ya bakan yeğeninin kendisini arayarak "hocasının ömrünün son zamanlarını yaşadığını" haber vermesi üzerine maddi imkânsılıklara rağmen bütün şartları zorlayarak uzun aktarmalı uçuşlar neticesinde, ömrünün son günlerini geçiren hocasını görüp elini öpebilmiştir. Seyda olarak zikrettiği, Siirtli (Velayeli) Hocası Şeyh Müşerref' in ${ }^{25}$ elini öpmek için Diyarbakır ve Batman üzerinden oldukça meşakkatli bir yolculuğa katlanmıştır. ${ }^{26}$ Muhammed Hamidullah ve Tayyip Okiç Hocalar için sempozyumlar organize etmiştir. Bunların yanı sıra, Mehmet Akif Ersoy'u yad etmek adına her Kahire'ye gittiğinde milli şairimizin oturduğu "Kahve Fişavi"de bir kahve içmesi ${ }^{27}$ onun vefa adına ne kadar büyük bir kadirşinaslık gösterdiğini aktarmak için yeterli örneklerdir. Bahsi geçen dostluk ve vefa örnekleri, Hoca'nın seyahatlerinin güzergâhının şekillenmesinde önemli bir yer tutmuştur.

\section{Eserlerindeki Görsel Malzeme}

Seyahatnamelerde görsel malzeme kullanımı yüzyıllar öncesine dayanmaktadır. Bilhassa Avrupalı seyyahların eserlerinde rastlanan resimlerle anlatım, konunun uzun uzun yazılarla betimlenmesinden daha etkili şekilde anlaşılmasına imkân sağlamaktadır. Her ne kadar resimler bazen sonradan eklenerek basılsa da, bazı seyyahların gördüklerini bizatihi resmettikleri de eserlerdeki ifadelerden anlaşılmaktadır. İhsan Süreyya Hoca ise yanından hiç ayırmadığ 1 fotoğraf makinasıyla sürekli fotoğraf çekmek suretiyle seyahat eserlerini zenginleştirmiştir. Bu görsellerde sadece mimari yapıların, dağların veya şehirlerin görüntülerine yer vermemiş aynı zamanda dostlarının veya gittiği yerde gördüğü herhangi bir insanın fotoğrafını da paylaşarak bir anlamda paylaştığı kişileri hem onurlandırmış hem de unutmadığını göstermiş̧tir.

Süreyya Hoca'nın eserlerindeki metin içi ve eser sonu görsellerin varlığı gezilen coğrafyayı ve insanını tanımada yardımcı olan önemli bir detaydır. Her ne kadar söz konusu görseller seyahat eserlerinde kullanımış olsa da bu eserlerde kullanılan malzemeler seyahatnameler dışında hocayı anlatan "Pervari'den Paris'e" adlı söyleşi kitabında daha fazla görülmektedir. ${ }^{28}$ Bunların dışında İhsan Hoca'nın, -kendisinden duyduğum kadarıyla- özel arşivinde ayıklanmayı bekleyen binlerce fotoğrafı mevcuttur.

\section{Gezilen Yerlerin Yemekleri}

İhsan Süreyya Hoca, gittiği memleketlerin günlük yaşamını takip etmekle beraber, bulunduğu ülkenin yemek kültürünü öğrenmek için özellikle yöresel yemeklerin tadına bakmayı ihmal etmemiştir. Hatta yöresel yemekleri de yine bölge insanının yediği şekilde yemeye özen gösterdiği anlaşılmaktadır. Bunların başında Çin mutfağından bazı yemekler gelmektedir. Çin' deki bir lokantada "Hotpot" adında bir yemeği tadan Hoca,

\footnotetext{
${ }^{25}$ Şeyh Müşerref'in, İhsan Süreyya Sırma'nın eğitim hayatının önünü açan bir zat olduğu önceki kısımda belirtilmişti.

${ }^{26}$ Sirma, Seyahatnâme-i Süreyya, 197-198.

${ }^{27}$ Sirma, Seyahatnâme-i Süreyya, 214-216.

${ }^{28}$ Demircan, Ihsan Süreyya Sirma Kitabi. Pervari'den Paris'e.
} 
Çinlilerin kullandıkları çubuklarla mücadele vererek yediği yemeği okuyucuları için etraflıca anlatmayı ve fotoğrafinı paylaşmayı uygun görmüştür. ${ }^{29}$

Bununla birlikte Yemen'e özgü "Fahsa yemeği" "30 ve Sudan'da yediği "Taş Kebap"31 dışında genelde balık ürünlerini tercih ettiği göze çarpan Tarihçi Seyyahın, Kanada'da yediği “Maple Syrup"la pişirilmişs somon balığ l" 32 ile Dubai'de tattı̆̆ 1 "Hamur ve Waili balıkları" 33 bunlardan sadece bir kaçıdır.

Hoca'nın Şafii Mezhebine mensup olması deniz ürünleri konusunda daha rahat hareket etmesine olanak sağlasa da, yemekler konusunda İslami usullere aykırı olmayan ürün ve yiyecekleri tercih ettiği görülmektedir.

\section{Seyahatlerinde Dağlar ve Nehirlerin Yeri}

İhsan Süreyya Hoca, dağları anlattığı kitabının adını "Dağların Sırrı" olarak belirlemiş, muhtevasında da dağların barındırdığı sırrı aramıştır. Asıl maksat zirvelerin tadını çıkartmak değil, dağların saklı gizemlerini araştırmaktır. ${ }^{34}$ Nehirleri anlattığı eserine ise "Nehirlerin Dili" adını vermiştir. Tarihçi mahlasına uygun şekilde tarihi geçmişi olan dağları ve nehirleri ziyaret eden seyyahın tuttuğu notlarda dikkat çekici olan iki husus vardır. Bunlardan birincisi, dağların Kur'an-1 Kerim ile olan bağlarını kurarak hikâyesini anlatmas1; ikincisi ise, biraz kurgusal biraz da gerçekle bağdaştırarak yaşanmış hikâyeleri "Tarihçi" karakteriyle dağların eteklerinde ve nehirlerin kenarındaki olağan dışı izler veya nesneler üzerinden anlatmasıdır. Bu bağlamda dağların ve nehirlerin Tarihçi Seyyah'a sunduğu birçok yaşanmışlık vardır. İç içe geçmiş gerçeklikler ve kurgusal hikâyeler bir seyyahın hayal dünyasında da seyahat ettiğinin çarpıcı bir örneğidir.

Tarihçi Seyyah, "Verin bana dağlarl, sizin olsun ovalar" 35 diyerek dağlara olan hayranlığını çevresindeki herkese duyuran bir kişidir. Dağlar onun gözünde Allah'ın Kur'an'da ifade ettiği gibi, "Dünya'nın kazıklarıdır"36. Bu sebeple görülmesi ve tefekkür edilmesi gereken haşmetli yerlerdir/varlıklardır. İhsan Hoca, dağların kıymetini Tur Dağı'nın ${ }^{37}$ Kur'an'da bir sure adı olmasına gönderme yaparak da vurgulamıştır.

Dağları anlatmaya, insanlığın atası olan Hz. Âdem Peygamberin Hz. Havva ile buluştuğu Arafat Dağı'yla başlayan Tarihçi Seyyah, eserine insanlığın ikinci atası kabul edilen Nuh Peygamber'in gemisinin indirildiği belirtilen Cudi Dağı'yla devam eder. Ardından Hz. İbrahim Peygamberi ateşe atan hükümdarın isminin verildiği Nemrut Dağı ve Musa Peygamber'in Allah (CC.) ile konuşmak için çıktığ 1 Tur Dağ gelmektedir. Velhasıl gezdiği birçok dağı hem tarihsel bir süreklilikle hem de Kur'an-1 Kerim'deki ayetler ile bağlantı kurarak okuyucuya sunmaktadır. Tarihçinin gördüğü dağların hepsinin de daima yanında taşıdığı kalem ile yanından ayırmadığı not defterine yazılacak mutlaka bir hikâyesi vardır.

Dağa çıkmak için Tarihçi Seyyahın yanına aldığı temel şeyler şunlardır: "su, not defteri, kalem, baston ve ihtiyaç halinde değiş̧eceği kıyafet". Taishan Dağı'na çıkarken yanına

\footnotetext{
${ }^{29}$ İhsan Süreyya Sırma, Çin Müslümanlart ve Çin'e Seyahat (İstanbul: Beyan Yayınları, 2008), 94-96,97.

30 İhsan Süreyya Sirma, Ano Yemen'dir (İstanbul: Beyan Yayınlar1, 2010), 52.

${ }^{31}$ Sirma, Seyahatnâme-i Süreyya, 35-36.

${ }^{32}$ Sirma, Seyahatnâme-i Süreyya, 147.

${ }^{33}$ Sirma, Seyahatnâme-i Süreyya, 159.

${ }^{34}$ Sirma, Dă̆ların Sirrı, 59.

${ }^{35}$ Sirma, Dă̆ların Sirrı, 70.8

36 “Biz yeryüzünü bir döşek, dağları da birer kazık yapmadık mı?” Bk. Kur’an-1 Kerim, Nebe': 7.

37 Tûr, Kur'an-1 Kerim'de 52. siradaki surenin adıdır.
} 
$\overline{\text { aldığı bastona gelen ihtiyarlık göndermesine karşılık, "bastonu ihtiyarlı̆̆ın }}$ alametifarikası yerine, dăga çıkmak için lüzumlu bir alet ${ }^{38}$ olarak görmesi bugünkü yaşında (75) dahi elinde bastonla dolaşmamasına verilen güzel bir cevap niteliğindedir.

Tarihçi Seyyahın merak ve cesareti onun beklenmedik manzaralarla karşılaşmasını sağlamıştır. Örneğin Amerika kıtasındaki Kinto Dağı'na tırmanan Tarihçi, tırmanma rotasında karşılaştığ 1 "Danger (tehlike)" levhasını dinlemeden, devam etmiş ve toplu halde duran insan kemikleriyle karşılaşmıştır. Tehlike levhasını umursamaması, ona belki de bir daha rastlayamayacağı bir manzarayı göstermiştir. Ona göre bu kemikler Amerikalıların katlettiği Kızılderelilere aittir. ${ }^{39}$

İhsan Süreyya Hoca seyahatlerinde daima cesur, gözü pek ve yaşının gereği kendisinden beklenmeyecek kadar da dinçtir. Örneğin Nemrut Dağı'nda gece kalmalarına müsaade etmeyen güvenliğe direnmiş, arabasında üşümek pahasına geceyi ailesiyle birlikte dağda geçirmiş ve arabanın 1şı̆̆ını kullanarak İbrahim Peygamber'in Nemrut'la olan mücadelesini Nemrut Dağı'nın zirvesinde en derinden hissederek kaydetmiştir. ${ }^{40}$ Habîbu'n-Neccâr (Marangoz Sevgili) Dağı'na da yürüyerek çıkan Tarihçi, birçok defa olduğu gibi yanındakileri de yürütmüştür. Hatta Hz. Musa gibi Tur Dağı'na yürüyerek tırmanmak istemiş ancak bu emrin bir peygambere gönderildiğini hatırlaması üzerine ayakkabılarını yeniden giymiştir. $\mathrm{Bu}$ hareketlerin gayesi dağların kıssalarında yaşananları bir nebze olsun yaşayabilmek olmalıdır. ${ }^{41}$

Adeta kıssaların dağlarını arayan tarihçi seyyah, dağların kıssalarını da genellikle dağların zirvesindeki bir kayanın dibinde dinlenirken kaydetmiştir. Tarihçi, kavminin üzerine ateş yağan Sodom Dağı'nın kıssasını, Lut kavmine gönderilen felaket sonrası küle dönmüş kayaların üzerinde kaleme almıştır. Kendi ifadesiyle, bastığı taşların küle döndüğü Sodom Dağı, Lut Peygamberin yaşadıklarını kendisine haykırmıştır. İhsan Hoca'ya göre bu dağdan alınacak çok ders vardır. Çünkü günümüzde Lut Kavminin çirkefliğinin hududu kalmamış, Sodom'dan fersah fersah ötelere ulaşmıştır. İhsan Hoca, her kıssada ve dağda olduğu gibi burada da konuyu günümüze getirerek duyduğu rahatsızlığı dillendirmekle beraber, dua etmeyi de ihmal etmemiştir. ${ }^{42}$

Asya, Avrupa, Afrika, Amerika demeden dört kıtaya ayak basan tarihçi Seyyahın Çin'de bulunan Taishan Dağ'ına kadar uzanan yolculuğu Çin'e İslamiyet'i götüren Vehb b. Ebi Kebşe'yi anmasına, Konfiçyüs'ün ahlak öğretisini hatırlamasına vesile olmuştur. O Vehb ki, Çin'de daha uzun kalmak için izin istemek üzere Medine'ye döndüğünde Hz. Peygamberin vefatını öğrenmiştir. Bu defa izni Halife Ebubekir'den alıp ömrünün sonuna kadar Çin'de İ́slam'ı tebliğ etme şerefine nail olmuştur. ${ }^{43}$

Tarihçi Seyyahın belki de en ilginç seyahati II. Viyana Kuşatması'yla anılan Viyana'daki Kahlenberg Dağı'nda yaşadıklarıdır. Kahlenberg, Viyanalıların sıkça gittikleri ve bir kahve eşliğinde şehri temaşa ettikleri bir dağdır. Hem Avusturyalılar hem de Türkler için manidar bir geçmişe sahip olan bu yer, Tarihçi Seyyah için birçok dağ gibi özel ve hazin bir hikâye sunmuştur. Burası Osmanlı ordusunun Haçlı ordusuna yenildiği ve geri çekilmek zorunda kaldığı yerdir. Seyyahımız bu dağda yaşanan hikâyeyi ağaç kovuğundaki mektup üzerinden kurgulamıştır. Bu mektup; II. Viyana

\footnotetext{
${ }^{38}$ Sirma, Çin Müslümanlart ve Çin'e Seyahat, 152.

${ }^{39}$ Sirma, Dağların Sirrı, 101-106.

40 Sirma, Dağların Sirrı, 31-43.

${ }^{41}$ Sirma, Dağların Sirrı, 59-60.

${ }^{42}$ Sirma, Dağların Sirrı, 43-50.

${ }^{43}$ Sirma, Dağların Sirrı, 77-82.
} 
Kuşatmasına (1683) katılmış bir asker tarafından yazılmıştır. Mektup kuşatma hakkında detaylı malumatlar içermektedir. ${ }^{44}$

Tarihçi Seyyahın gezdiği en hüzünlü dağlar ise Allahuekber Dağları'dır. Dağa tırmandığında ayağına takılan bir şehidin kaburga kemiğini, yine itinalı bir şekilde toprağa, ait olduğu yere, gömen Tarihçi Seyyah, on binlerce askerimizi şehadete götüren "kar" için bir de şiir kaleme almıştır:

“...

Kaar...

Bir öykünü benden dinlemek ister miydin?

Bir varmış bir yokmuş diye.

Allahuekber Dağlarının

Sade sen ve buz kokan zirvelerinde

Seni tanımayan

Sorumsuz komutana itaat edip,

Soğuğa esir düşen,

Donup çekilen kanlara,

Vücutlarında buzdan akan damarlar oluşturan,

Kanları çekilince,

Vurulmuş ceylanlar gibi,

Yamaçlarda yuvarlanan biçare askerin,

Sapır sapır dökülen yiğitlerin

Buz kaşll, buz kirpikli heykel erlerin

Hemen tamami,

“Kaar! Kaar!” deyip gömüldüler içine...

Teker teker

Çifter çifter

Onar onar

..."45

Seyahat eserlerini güçlü kılan unsurlardan birisi, gezilen yerlerin hangi tarihlerde ziyaret edildiğidir. Bu bağlamda İhsan Süreyya'nın "Dağların Sırrı" adlı eserinde herhangi bir tarihlendirmenin olmaması bir eksikliktir. Ancak dağlarla ilgili güncel ve dönemi ilgilendiren toplumsal hadiselere değinilmemesi bu eksikliğin tolere edilmesini mümkün kılmaktadır.

İhsan Süreyya'nın seyahatlerinde dağların dışında hikâyelerine tanıklık eden diğer bir yaratılış mucizesi ise "nehirler"dir. Bundan dolayıdır ki

${ }^{44}$ Sirma, Dağların Sirrı, 115-121

${ }^{45}$ Sirma, Dağların Sirrı, 133. 
"Nehirlerin Dili" adlı eserini

"zaman zaman okuyucularımı bize, en çok hangi kitabımızı sevdiğimizi sorar ve bizden 'Nehirlerin Dili' cevabını alınca da şaşııır, 'ama Hocam, bu kitabınız hiç bilinmiyor' diye serzenişte bulunurlar. Insanların olduğu gibi kitapların da kaderi vardır: kimi kitaplar çok bilinir, çok satılır; kimi kitaplar da çok değerli olmalarına rağmen fazla bilinmez, ancak okunduktan sonra değerleri anlaşılır. Bizim 'Nehirlerin Dili' kitabımız da böyledir" ${ }^{\prime 46}$

cümleleriyle özel bir yere koymuştur. Bu eserin bir seyyah açısından dikkate değer tarafi; eserde kurgu ile gerçeklik arasında gidip gelen bir seyyah kimliğinin ortaya çıkmasıdır. Yani İhsan Süreyya Hoca, bizatihi yaşadığı olayları anlatan seyyah olmanın dışında, okuyucuyu zihnen de gezdiren bir seyyah kimliğini ortaya koymuştur.

İhsan Süreyya Hoca, Botan ve Dersim çayları ile Dicle, Aras, Nil, Tuna, Sen, Şeria, Meriç, Amazon ve Volga nehirleri gibi hem Anadolu'da hem de dünyanın birçok yerinde bulunan akarsuları görmüş ve bu akarsuların kendisine sunduğu yaşanmış hikâyelere kulak kabartmıştır. Unutulmaz hakikatler içeren bu hikâyeler, ancak onlarca yılını gezerek yine onlarca ülke ve nehir gören meraklı bir Tarihçi Seyyahın kaleminden çıkabilirdi.

Tarihçi Seyyah, okuyucuya yukarıda bahsi geçen nehirlerin kıyısında şaşırtıcı tecrübeler yaşamaktadır. Örneğin Avusturalya'daki Murayy Nehri kenarındaki balıkçının oltasına takılan çamurlu cüzdanı temizlemesiyle ortaya çıkan mektuptur. I. Dünya Savaşı döneminde yazılan bu mektubun hikayesi okuyucuyu bir asır öncesine götürmektedir. Broken Hill Tepesi Hadisesi olarak da bilinen bu hikâyede Asyalı iki Müslüman, Avusturalyalı askerlerin Müslümanlarla (Osmanlı Devleti) savaşmak için Anadolu'ya gideceklerini duymuş, Halifenin cihat ilanının da haberini almışlardır. Bunun üzerine sözkonusu askerler, düşman askerlerini taşıdığını düşündükleri trene saldırı yaparak 4 kişiyi ${ }^{47}$ öldürmüş, ancak kendileri de bu saldırıda şehit düşmüşlerdir. İşte Tarihçi Seyyahın bahsettiği mektup, bu askerlerin şehit olmadan önce kaleme aldıkları mektuptur. ${ }^{48}$

Tarihçi Seyyah, Avusturalya'nın Murayy'ındaki Çanakkale kahramanlarını, Ürdün'ün Şeriyya Vadisi'ndeki Filistinliyi, ${ }^{49}$ Nil'in kenarındaki hazin Mısır hikayesini, nehirleri vesile kılarak aktarmıştır. Böylece nerede bir zulüm veya Müslümanların yaşanmış çilesi varsa, onu nehrin hikayesi olarak bir zihin seyahatine dönüştürmüştür.

\section{Farklılıkların Ülkesi: Çin}

İhsan Hoca, Çin'e yaptığı yaklaşık iki hafta süren gezisinde önemli tecrübeler edinmiştir. Bir davet sonucu Çin'e giden Hoca, özellikle Müslümanların yaşamlarını konu edinmiş olmakla beraber Çin'in içtimai yaşamına özgü oldukça geniş malumatlar vermiştir. Tam bir merak duygusuyla gezdiği 12 gün, bilhassa Müslümanların

\footnotetext{
${ }^{46}$ Sirma, Nehirlerin Dili, 7.

${ }^{47}$ Kurgusal bir mektup hikayesiyle başlayan olayı eserine taşıyan İhsan Süreyya Hoca'nın verdiği ölen asker sayısı (260) oldukça abartılıdır. Bu sayıyı teyit edecek herhangi başka bir kaynağa ulaşılamamıştır. Buradaki ölen insan sayısının saldırıyı yapan iki Müslüman ile beraber toplamda 6 kişi olduğu belirtilmekle beraber bu sayının da yanlış olabileceği göz ardı edilmemelidir. Söz konusu hikaye 1. Dünya Savaşı'nın popülist bir tarih miti olmasının dışında sinema sektörüne de yansımıştır. Mezkur hadisenin eleştirel bir süzgeçten geçirilerek incelenmesi dönemin "propaganda" siyasetini anlamak açısından elzemdir. İlgili kaynak için bk. Ekram Saltık, “Anzak Komplosu”, Osmanlı'nın Son Kilidi Çanakkale 2, Nşr. Harun Tuncer ve Ahmet Temiz, (İstanbul: Çamlıca Yayınları, 2015), 95-122.

${ }^{48}$ Sirma, Nehirlerin Dili, 63-68.

${ }^{49}$ Sirma, Nehirlerin Dili, 97-102.
} 
yaşadıkları yerlerde geçmiştir. Hoca, bu ülkedeki Müslüman nüfusunun beklediğinden daha fazla olduğunu müşahede etmiştir. Çin hakkında hayli olumlu bir intiba edinen İhsan Süreyya Hoca birçok eserinde olduğu gibi Batı kültürünün Çin'in en kutsallarının içine girmesinden de rahatsızlık duymuştur.

Çin'in alışılması zor kültürü ise yabancı yemek çeşitleri ile bu yemekleri yiyebilmek için kullanılan ve Batı dünyası için nostalji olarak görülen yemek çubuklarıdır. Yemeklerin servisinden önce sunulan yeşil çaya, soğan tatlısı gibi alışılmadık tatlı türlerine, Karadenizlilerin hamsisi gibi her türlü yemek ve tatlının vazgeçilmezi olan pirinç ile sonunda ikram edildiği anlaşılan çorbaya kadar Çin'in yemek kültürü hakkında bizatihi yaşadığı tecrübeleri aktaran Tarihçi Seyyah, bunların hepsini de deneyerek okuyucuya birinci ağızdan aktarmıştır.

İhsan Süreyya Sırma'nın yaklaşımından anlaşıldığı kadarıyla; Çin'deki Müslümanlar samimi, Arapçayı Çince telaffuzla konuşan, Arapça yazıları kendine özgü bir şekilde adeta Çince karakterlerle birleştirerek yazan "güzel” insanlardır. İmamların evlerine davet edilen Hoca'yı etkileyen önemli bir hadise ise, İmam Yahya'nın evinde rastladığ el yazması Arapça eserler ile yine el yazması Kur'an-1 Kerim cüzleridir. Söz konusu el yazmalarının birileri tarafından keşfedilerek Türkiye'deki kütüphanelere kazandırılması arzusunu ayrıca vurgulamıştır.

İhsan Hoca, Çin’i birçok açıdan sevmiş ve halkını samimi bulmuştur. Ancak onun bu ülkede tasvip etmediği şeyler de vardır. Bunların başında ise insanların buldukları her yere tükürme alışkanlıkları gelmektedir. ${ }^{50}$ Burada da Çinlileri güzel bir üslupla uyarmayı unutmayan İhsan Süreyya, Çin'de rastlamadığı dilencileri anmayı da ihmal etmemektedir. ${ }^{51}$

Seyahat notlarında Çin'in çocuk politikasından, paraların üzerindeki Arapça yazılara kadar ilginç bilgiler bulmak mümkündür. Çin devletinin tek çocuk politikası yakın zamana kadar medyaya da yansımıştır. Ancak İhsan Süreyya'nın verdiği bilgiler bunun ötesinde ve hayli ilginçtir. Ona göre, Çinliler tek çocuk, azınlıklar (Müslümanlar bunlara dâhil) iki, Müslüman olan resmi görevli imamlar ise üç çocuk sahibi olabilmektedir. ${ }^{52}$ Mantığını kavrayamadığımız bu bilgiyi seyyahın verdiği bilgilere itimat ederek olduğu gibi kabul etmek durumundayız..$^{53}$ Diğer ilginç ve bir o kadar da hayrete düşüren bilgi ise Çin paralarının üzerinde Osmanlıca olarak "Cuncu Halk Bankası" ibaresinin bulunmasıdır. ${ }^{54}$

Birçok yerde olduğu gibi Çin'de de Batı ve Batı'nın markaları ile Amerika'yı eleştiren Tarihçi Seyyahın Çin-Batı karşılaştırması yaptı̆̆ 1 şu cümlesi oldukça manidardır: "Bir Müslüman olarak Amerika'da yaşamaktansa, milyon sene Çin'de yaşamayı tercih

\footnotetext{
${ }^{50}$ Sırma, Çin Müslümanlarl ve Çin'e Seyahat, 68.

${ }^{51}$ Sırma, Çin Müslümanlarl ve Çin'e Seyahat, 69.

${ }^{52}$ Sirma, Çin Müslümanlarl ve Çin'e Seyahat, 128.

${ }^{53}$ Doğu Türkistan hakkındaki bir araştırmaya göre; Doğu Türkistanlılar köylerde iki şehirlerde bir çocuk sahibi olabilmektedirler. Ayrıntılı bilgi için bk. Gül Seda Acet İnce, "Çin'in Vahşi Yüzü: Doğu Türkistan Zulmü Ve Uluslararası Toplumun Sorumlulukları", Avrasya Sosyal ve Ekonomi Araştırmaları Dergisi (ASEAD) 6/4 (2019): 578.

54 İhsan Hoca bu bilgilerin doğruluğunu kanıtlayan para örneklerinin fotoğrafını paylaşmıştır (Sırma, Çin Müslümanları ve Çin'e Seyahat, 120). Osmanlıca yazılmış bu bilgilerin kökeni Çin'de yaşayan Uygur Türklerinden ve kullanmaktan vazgeçmedikleri Arap alfabesinden kaynaklanmaktadır. Yani Türkçe kökenli olan bu yazılar Arap alfabesiyle yazılmıştır. Ayrıntılı bilgi için bk. Radikal Gazetesi, "Çin Parasının Üzerinde Osmanlıca Ne Arıyor”, erişim: 21.09.2019, http://www.radikal.com.tr/yazarlar/guvensak/cin-parasinin-uzerinde-osmanlica-ne-ariyor-1258953/
} 
ederim." 55 Bu cümleye Seyahatnâme-i Süreyya adlı eserinde şöyle devam etmiştir: "Doğrusu, Amerika kitasına geldiğim ilk seferden bu güne kadar, hiçbir zaman bu kıta içime sinmedi ve burada yaşamak içimden geçmedi." 56

\section{En Çok Görmek İstediği Ülke: Yemen}

Evvel emirde belirtmek gerekir ki İhsan Süreyya Hoca'nın gönlünde nakş etmiş iki yer vardır. Bunlardan birisi Pervari, yani doğduğu yer; diğeri ise, Yemen'dir. Gezmeye doyamadığı Yemen'e yine bir ilmi program daveti için gitmiş ve tebliğ sunan hocalar dönmesine rağmen doçentlik tezinin konusu olan Yemen'i gezmeden, Yemenli dostlarını görmeden dönmemek adına, birkaç gününü daha bu topraklarda geçirmiştir. Hemen dönmeyerek, biraz daha gezerek günümüzde savaşlarla anılan Yemen'in ${ }^{57}$ güzel günlerini okuma firsatı bulmuştur.

Yemen'e gitmeden evvel Viyana'nın Yemen konsolosluğuna giderek ülke hakkında bilgi edinme çabası, Yemen'e verdiği değerden ziyade gidilen coğrafyayı tanımak, mutlaka görülmesi gereken yeri ziyaret etmek için bir seyyah adına iyi bir yöntem olmuştur.

İhsan Süreyya Hoca, Çin'de olduğu gibi Yemen'de de birçok kültürel objeyi inceleme ve buradaki yemeklerin tadına bakma firsatı bulmuştur. Bu ülkede onun dikkatini çeken şeylerin başında, bilhassa Kuzey Yemenlilerin vazgeçilmezi olan "Cenbiye" ile "gat tahzini" gelmektedir. Cenbiye dışardan eğik uçlu kabzası olan ve bütün Kuzey Yemenlilerin üstlerinde taşıdıkları bir hançerdir. Gat ise yaprakları çiğnenerek uzun süre ağızda tutulan uyuşturucu etkisi olan bitkiye denmektedir. İhsan Hoca bu bitkinin bütün Yemen'i sardığını ve "Kahve Yemen'den gelir" türküsüne kaynaklık eden kahve bitkisi gibi birçok bölgesel bitkinin kesilerek yerine dikilmesini ciddi şekilde eleştirmiştir. ${ }^{58}$

Hoca, bir yere gittiğinde herkesin gittiği modern ve göz alıcı mimari yerine ilmi sahasına uygun olarak kadim olanı görmeyi arzuladığından, Yemen'de de altı minareli büyük ve modern bir camide namaz kılma teklifini geri çevirmiş, San'a'daki Câmiü'lKebir'de namaz k1lmayı tercih etmiştir. ${ }^{59}$

Tarihçi Seyyahın Yemen'de karşılaştığı ve birkaç yerde daha değindiği bir konu da dilencilerdir. Bu insanlar, İhsan Hoca'nın hassas olduğu konulardandır. Zira Hoca, -ben de birçok defa şahidim ki- kendisinden bir talebi olan dilenciyi geri çevirmez ellerine birkaç lirayı sıkıştırarak yoluna devam eder. Ancak Hoca'nın Yemen'de karşılaştığı dilencilerin ayrı bir yeri vardır. Herşeyden önce bu insanlar ona göre arsız değil aksine edeplidirler. Örneğin, verdiği paradan sonra bir fotoğraf çektirmek istediğini söylediği küçük bir dilenci kız -fotoğraf için para verdiğini zannederek- bu talep karşısında parasını iade etmiş ancak Hoca, parayı bunun için vermediğini söyleyerek geri vermiş ve uzaklaşırken küçük kızın; "seni üzdüğüm için affet ve lütfen fotoğrafımı çek" demesi, onu hayli etkilemiştir. ${ }^{60}$

\footnotetext{
${ }^{55}$ Sirma, Çin Müslümanlart ve Çin'e Seyahat, 104.

${ }^{56}$ Sirma, Seyahatnâme-i Süreyya, 151.

${ }^{57}$ Hoca, gittiği yıllarda henüz iç savaşa "sürüklenmemiş" Yemen hakkındaki olası savaş ihtimaline vurgu yaparak Amerika'ya gönderme yapmıştır. Günümüzde bu göndermenin haklılığı ortaya çıkmaktadır.

${ }_{58}$ Sirma, Ano Yemen'dir, 42-43.

${ }^{59}$ Sirma, Ano Yemen'dir, 46.

${ }^{60}$ Sirma, Ano Yemen'dir, 106-107.
} 
İhsan Süreyya Hoca, çocukları sevindirmeyi de ihmal etmemiştir. Örneğin Yemenli çocukların değersiz taşları çok değerli diyerek 10 Dolara satmasına karşılık 1 Dolar etmeyecek taşı 5 dolara alacak kadar düşünceli bir tarafı vardır. ${ }^{61}$

Yemen gezisi onun için vazgeçilmez olduğu kadar tamamlanamamış bir seyahat olmuştur. Dönerken adeta içinde kalan ukdeleri tekrarlayarak geçmişin seyyahlarına atıfta bulunarak onlar gibi bir ailenin yanında biraz vakit geçirmenin, ulemasıyla sohbet etmenin, dağlarına arabayla değil de bastonuyla çıkmanın özlemini dillendirmiştir. ${ }^{62}$ Ancak uzun kalamayışının da temel sebebi günümüz seyyahlarının asli sorunlarından birisi olan para meselesidir.

\section{SONUÇ}

İhsan Süreyya Sırma, hayatının önemli bir kısmını gezerek, gözlemleyerek ve sorgulayarak geçirmiş çağdaş bir "Tarihçi Seyyah”tır. Şahit olduğu olayları büyük küçük demeden kaydetmiş, yüzlerce sayfayı bulan seyahatnameler üretmiştir. Bu eserler Müslüman bir alimin seyyah gözüyle dünyayı "Müslümanca" anlama ve anlamlandırma çabasının ürünüdür.

İhsan Süreyya Hoca'nın dikkatli ve meraklı gözerle etrafı taraması veya başkalarının umursamadan geçtiği "küçük şeyleri" sorgulaması, ona yazacak daha fazla hikâye çıkartmıştır. Yıllarca biriktirilen zarflarda muhafaza edilen notları, bir araya getirilerek sürükleyici seyahatnamelerini neşretmiştir. Hoca'nın seyahat notları arasında özet ama arkasında uzun hikâyeler barındıran konulara rastlanmaktadır. Bunlar bazen şaşırtıcı bazen de kurgusal olarak anlatılan bir hikâyenin, hakkında araştırma yapıldığında dipsiz derinliklere götüren bilgiler ihtiva etmektedir.

İhsan Hoca, eserlerini okuyucuya karşı sorumluluk duygusuyla kaleme almış, eriştiği bilgiler ve eserler dışında gezdiği yerleri de okuyucunun aynı yere gittiğinde gözden kaçırmasını istemediği hususlar çerçevesinde sunmuştur. Bu sorumluluk duygusu kitap aşığı bir insan olan Süreyya Hoca'nın seyahat ettiği yerlerdeki eserleri tanıtma çabasında da ortaya çıkmaktadır. Ayrıca seyahat notlarında ilim adamlarını da tanıtmayı ihmal etmemiş hatta bunu bir görev ve vefa bilinciyle yapmıştır. Wolf Dieter Hütteroth, Roger Garaudy, Salim Abdullah, Said Ramazan gibi önemli kişilikleri hem tanıtmış hem de bazılarının görsellerini paylaşmıştır.

Seyahat notlarındaki bazı bilgilerin tekrar olması ve kurgu ile gerçekliğin kimi eserlerinde iç içe olması, yapıcı bir eleştiri olarak, belirtilmesi gereken hususlardandır. Eserlerde yoğun olarak kullanılan görseller ise günümüz seyyah kimliği ve kendi renkli kişiliğini yansıtan önemli bir detaydır.

Sonuç olarak kendini "Tarihçi”" olarak niteleyen İhsan Süreyya Sırma, derdi olan bir Müslüman, meraklı bir ilim adamı ve gezmeyi seven bir seyyah olarak en yalın haliyle; okuyucuya "dünyayı" tanıtan "Müslüman bir Seyyah"tır.

\section{KAYNAKÇA}

Demircan, Adnan. İhsan Süreyya Strma Kitabi. Pervari'den Paris'e. İstanbul: Beyan Yayınlar1, 2018.

\footnotetext{
${ }^{61}$ Sirma, Ano Yemen'dir, 121-122.

62 Sirma, Ano Yemen'dir, 141.
} 
Saltık, Ekram. “Anzak Komplosu”. Osmanlı’nın Son Kilidi Çanakkale 2. Nşr. Harun Tuncer ve Ahmet Temiz. İstanbul: Çamlıca Yayınları, 2015.

Sırma, İhsan Süreyya. Seyahatnâme-i Süreyya. İstanbul: Beyan Yayınları, 2010.

Sırma, İhsan Süreyya. Yalan Dünyayı Adımlarken. İstanbul: Beyan Yayınları, 2011.

Sirma, İhsan Süreyya. Ano Yemen'dir. İstanbul: Beyan Yayınları, 2010.

Sırma, İhsan Süreyya. Çin Müslümanları ve Çin'e Seyahat. İstanbul: Beyan Yayınları, 2008.

Sırma, İhsan Süreyya. Dağların Sırrı. İstanbul: Beyan Yayınları, 2017.

Sırma, İhsan Süreyya. Nehirlerin Dili. İstanbul: Beyan Yayınları, 2017.

İbn-i Batuta. Büyük Dünya Seyahatnamesi. İstanbul: Yeni Şafak, (tarih yok).

Busbecq Ogier Chiselin de. Türk Mektupları. Kanuni Döneminde Avrupalı Bir Elçinin Gözlemleri (1555-1560), Trc. Derin Türkömer. İstanbul: Türkiye İş Bankası Kültür Yayınları, 2016.

Acet İnce, Gül Seda. "Çin'in Vahşi Yüzü: Doğu Türkistan Zulmü Ve Uluslararası Toplumun Sorumlulukları”. Avrasya Sosyal ve Ekonomi Araştırmaları Dergisi (ASEAD) 6/4, (2019): 572-584.

Radikal Gazetesi, "Çin Parasının Üzerinde Osmanlıca Ne Arıyor”, erişim: 21.09.2019, http://www.radikal.com.tr/yazarlar/guven-sak/cin-parasinin-uzerinde-osmanlica-neariyor-1258953/ 